Article

\title{
Walking the Walk or Just Talking the Talk? VMRO-BND's Efforts to Become a Mass Party
}

\author{
Petar Bankov ${ }^{1}$, Sergiu Gherghina ${ }^{1}$ and Nanuli Silagadze ${ }^{2, *}$ \\ ${ }^{1}$ School of Social and Political Studies, University of Glasgow, UK; E-Mails: petar.bankov@glasgow.ac.uk (P.B.), \\ sergiu.gherghina@glasgow.ac.uk (S.G.) \\ 2 Faculty of Social Sciences, Business and Economics, Åbo Akademi University, Finland; E-Mail: nanuli.silagadze@abo.fi \\ * Corresponding author
}

Submitted: 28 May 2021 | Accepted: 9 September 2021 | Published: 24 November 2021

\begin{abstract}
Many populist radical right parties compete on a regular basis in the Bulgarian legislative elections. Among these, the VMRO-Balgarsko Natsionalno Dvizhenie (VMRO-BND, IMRO-Bulgarian National Movement) enjoys the greatest organizational stability and maintains a regular presence in politics and society despite volatile electoral performance. Using qualitative content analysis of official party documents (programs, statutes, and policy papers) and media reports, this article argues that the organizational stability of the VMRO-BND stems from its grassroots efforts to establish deep links in society. While its membership is limited, the local activities of the party between and during elections, and its network of looselyaffiliated organizations create a grandiose impression of presence across Bulgaria. Through this presence, VMRO-BND fosters a sense of belonging for its members which in turn supports the party's goal of achieving a so-called "national cultural unity" and the preservation of Bulgarian traditions. Internally, VMRO-BND provides room for non-member participation and bottom-up initiatives from local activists, while remaining strongly centralized at the top around its leader, Krasimir Karakachanov. Overall, VMRO-BND reveals the importance populist radical right parties place on social presence, even when membership numbers are low.
\end{abstract}

\section{Keywords}

Bulgaria; grassroots activities; mass party; organizational centralization; VMRO-BND

\section{Issue}

This article is part of the issue "Right-Wing Populist Party Organisation Across Europe: The Survival of the Mass-Party?" edited by Daniele Albertazzi (University of Surrey, UK) and Stijn van Kessel (Queen Mary University of London, UK).

(C) 2021 by the authors; licensee Cogitatio (Lisbon, Portugal). This article is licensed under a Creative Commons Attribution 4.0 International License (CC BY).

\section{Introduction}

Populist radical right parties (PRRPs) continue to have a significant presence in Bulgarian politics. Since the breakthrough of Ataka (Attack) in the 2005 parliamentary elections, PRRPs have continued to gain seats in the National Assembly, including in the April and July elections of 2021. Following the legislative elections in 2017, a five-party electoral alliance called Obedineni Patrioti (OP, United Patriots) served as a minor partner in a coalition government with the center-right Grazhdani za Evropeysko Razvitie na Bulgaria (GERB, Citizens for European Development of Bulgaria) after gaining 9.3\% of the vote (Central Electoral Commission, 2017). The cen- tral role in this alliance belongs to the VMRO-Balgarsko Natsionalno Dvizhenie (VMRO-BND, IMRO-Bulgarian National Movement). Founded in 1990, the VMRO-BND struggled electorally but has gained parliamentary seats in most elections since 1994. Currently, party finds itself as the main force within the populist radical right spectrum in Bulgaria. In the 2019 European Parliament elections, the party received $7.4 \%$ of the votes, winning two seats. Its main partners in the OP alliance, Ataka and Natsionalen Front za Spasenie na Bulgaria (NFSB, National Front for the Salvation of Bulgaria), received around $1 \%$ each (Central Electoral Commission, 2019).

As part of a thematic issue on the organization of PRRPs, this article analyzes the contemporary state of 
the organization of VMRO-BND. We analyze this party because of its dominant role and organizational longevity in relation to the other main actors within the radical right milieu in Bulgaria, such as Ataka and NFSB, which emerged after VMRO-BND in the mid-2000s and mid-2010s. VMRO-BND has made several attempts to become a mass party through drives to recruit activists, grassroots efforts on the ground, and through advocating the preservation of collective identities through ideology. The insights gained from this case are useful for understanding the development of a PRRP from Central and Eastern Europe and the behavior of a party with an extensive organizational tradition. Previous research has paid little attention to VMRO-BND and its organization, instead giving greater attention to the case of Ataka and its ideological profile when examining the policies, activities, and electoral development of the radical right scene in Bulgaria (Avramov, 2015; Ibroscheva, 2020; A. Krasteva, 2016; Sygkelos, 2015; Todorov, 2013; Werkmann \& Gherghina, 2018; Zankina, 2017). These studies echo the overall focus on topics around the ideology and political positions and actions of PRRPs in Central and Eastern Europe (Gherghina et al., 2017; Kopecký \& Mudde, 2003; Mesežnikov et al., 2008; Minkenberg, 2015, 2017; Pirro, 2015; Pytlas, 2016), yet they also present a significant gap in our understanding of the organizations of PRRPs.

VMRO-BND has the potential to become a mass party organization given its active membership (Ivanov \& Ilieva, 2005; Spirova, 2005). By taking a closer look at its organization, this article shows that VMRO-BND creates the impression that it is a mass party mainly due to its relentless grassroots work, close affiliations with the radical and extreme-right subcultures, and strong online presence. The party organization provides opportunities for activists to engage in local initiatives and communicate with larger society through the nomination of ordinary voters (non-members) on electoral lists. This openness, however, cannot hide VMRO-BND's declining and diffuse membership, as well as its strong centralization around the party leader and his close affiliates. In such circumstances, the efforts of VMRO-BND to present itself as a mass party relate to three main elements: its origins as a cultural organization striving to reach out to communities and spread nationalist messages; its aim to maintain strong links with local communities to draw support and recruit new members; and its goal to advocate nationalist ideas and gain widespread social acceptance. Ultimately, by keeping an active but small party organization, VMRO-BND creates a sense of belonging for its members while simultaneously mainstreaming its nationalist ideology.

We provide evidence for our argument using qualitative content analysis of official party documents (program, statute, policy papers) and media reports about the party's activities. Our choice of methodology reflects the framework of the thematic issue, which focuses on the extent to which right-wing populist parties have adopted the mass party model. The analysis derives from a systematic study of the party activities using reports in traditional media (mainly national and regional newspapers, including Trud, 24 Chasa, Dnevnik, Kapital, Mediapool), as well as the party's self-reported actions on its website. Very helpful in this respect was the Wayback Machine website that kept a relatively comprehensive archive of the VMRO-BND website dating back to the early 2000s. This data has been analyzed inductively through a two-step process where each report was initially coded according to the particular activity, followed by a subsequent coding where the already coded reports were re-coded according to a broader theme, such as political rally, commemoration, members' inauguration, among others. We have purposefully not looked for patterns related to the frequency or place where such activities occur, as this is beyond the scope of this article. Rather, we were focusing on what the party does so that we could establish whether VMRO-BND is capable and willing to mobilize activists and reach out to wider society. Our timeframe has been constrained by the availability of media reports. We have looked into the party's activities mainly in the past decade (2010-2021) in order to provide a contemporary picture of its organization.

In terms of online activities, an important aspect identified in the theoretical framework of this thematic issue, we analyzed the social media and other online channels maintained by the party and its main cadre (members of its executive committee, MPs, and MEPs). More specifically, we were interested in how often these channels post new content and what the nature of that content was (original posts or re-posts, article links or video/audio content, pictures, etc.). Our starting point was an existing argument in the literature according to which established channels of communication, be that social media, forums, newsletters, or emails, allow parties to better connect with the electorate and members (Werkmann \& Gherghina, 2018). Regarding internal party life, we relied on party statutes to provide a picture of the official state of internal party democracy. We used media reports covering party congresses and the candidate selection for national elections to understand the internal party dynamics in practice.

The remainder of this article is structured as follows: The next section outlines the organizational and electoral history of the VMRO-BND, as well as its ideological profile; the third section discusses the formal organizational structures and rules of VMRO-BND, followed by a discussion on its internal democracy in practice. The conclusion discusses the broader relevance of the organizational experiences of VMRO-BND for the study of PRRP organizations in Europe.

\section{The History, Ideology, and Electoral Evolution of VMRO-BND}

According to the party website (VMRO, 2012a), VMRO-BND was founded on 5 January 1990. Until 1999 
it existed as a nationalist cultural organization called VMRO-Sayuz na Makedonskite Druzhestva (VMRO-SMD, IMRO-Union of Macedonian Societies). The organization advocated for the Bulgarian character of Macedonia and promoted Bulgarian interests in North Macedonia and among Macedonian emigrant organizations. In this respect, the party claims to be a descendant of Vatreshna Makedonska Revolyutsionna Organizatsiya (VMRO, Internal Macedonian Revolutionary Organization), the main organization of the Macedonian liberation movement from the late 19th and the first half of the 20th century (VMRO, 2020b). Nevertheless, VMRO is used solely as an abbreviation and is never included in the party name in its entirety. Despite not being a political party per se, VMRO-SMD gained two parliamentary seats in 1994 and 1997 through participating in the electoral lists of the Union of Democratic Forces, the main center-right party in Bulgaria during the 1990s and early 2000s. In 1997, VMRO-SMD elected Krasimir Karakachanov as its president, who in 1999 transformed it into a political party and changed the name to VMRO-BND.

Ideologically, VMRO-BND is socially conservative and economically protectionist. In its current party program passed in 2012, VMRO-BND claimed that the main challenge for Bulgaria would be the "demographic catastrophe" (VMRO, 2020d). The party promotes a local version of the Great Replacement conspiracy theory, claiming that by 2050 ethnic Bulgarians will become a minority at the expense of the Roma community (VMRO, 2020a). In order to turn this trend around, VMRO-BND demands radical social and educational reform. The party has closely interlinked the replacement narrative with populism. This is particularly visible in its continued activism in opposition to what it calls "the Gypsy question." Here, VMRO-BND claims that all major social ills, such as declining education levels, rising poverty, and criminality, stem from the Roma community in Bulgaria and are tolerated by the political elites at the expense of Bulgarian citizens. In more recent years, the party has expanded this narrative and its policy demands by positioning itself as a protector of the "traditional Bulgarian family," thus projecting an image that all social minorities pose a threat to Bulgarian society (VMRO, 2021).

VMRO-BND calls for a radical conservative transformation of the country: It demands a new constitution that increases the powers of the Bulgarian president and declares Orthodox Christianity as the official national religion. In terms of foreign policy, VMRO-BND maintains the conservative idea of a "Europe of nations" and opposes the "federalization of the EU and its transformation into a superstate" (VMRO, 2020d). Consistent with the party's populism, the EU is regularly depicted by VMRO-BND activists and cadre as an organization that pursues a progressive agenda aimed at undermining the ethnic foundations of societies and states across Europe (Contrera, 2019). The party is also openly xenophobic, as it declares the EU accession of Turkey as "a serious threat to the existence of Bulgaria" (VMRO, 2020d). While its early programs paid considerable attention to irredentist claims toward North Macedonia, its current position has toned down these demands. The program instead notably includes a section on green politics, declaring the party support for "green nationalism," defined as "the idea that without nature, there is no Bulgaria" (VMRO, 2020d). Economically, VMRO-BND has changed its views significantly. While originally the party called for limited public expenses and a flat tax in the past (VMRO, 2008), its current program is noticeably more protectionist, with the aim of "support[ing]... the Bulgarian entrepreneurship against the challenges of the European and world markets" (VMRO, 2020d).

The party regularly participates in conservative and right-wing electoral alliances with a clear trend toward more ideologically compatible partners in recent years. During the 2000s and early 2010s, VMRO-BND joined seemingly unusual coalitions, including collaboration with moderately nationalist antisystem parties (Dvizhenie Gergiovden, St. George Movement), right-wing agrarians (Balgarski Zemedelski Naroden Sayuz-Naroden Sayuz, Bulgarian Agrarian People's Union-People's Union), and free-market conservatives (Sayuz na Svobodnite Demokrati/Union of Free Democrats, Partiya Lider/Leader Party, Edinna Narodna Partiya/United People's Party). Since 2014, VMRO-BND has joined the list of populist (Balgaria bez Tsenzura/Bulgaria Without Censorship) and PRRPs (NFSB, Ataka), thus strengthening its profile as a PRRP. The party gained parliamentary representation both before and after this strategic shift. In 2005, as part of the agrarian-conservative alliance Balgarski Naroden Sayuz (BNS, Bulgarian National Union), the party won $5.2 \%$ of the vote and had six out of the alliance's 13 MPs. In 2014 it joined the populist radical right NFSB in the Patriotichen Front (Patriotic Front) alliance, winning 7.3\% and eight seats out of the Patriotichen Front's 19. Then, in 2017, the Patriotichen Front was accompanied by the populist radical right Attack (and two minor parties), creating the OP alliance and gaining 9.3\%, with 11 of $27 \mathrm{MPs}$ belonging to VMRO-BND. Its 2017 electoral performance allowed the party to enter government, with Karakachanov becoming vice-prime minister and minister of defense. Additionally, the party won seats in the European Parliament in 2014 and 2019, while also participating in presidential elections since 2011 and providing support for conservative and center-right candidates. In 2011, Karakachanov won less than $1 \%$ of the vote, but in 2016 he was the OP joint candidate and came third with $15 \%$ on an anti-immigration and rule-of-law platform. Having risen electorally by 2019, VMRO-BND strived to present itself as a mass party. On the one hand, the party is very active locally and maintains strong links to an extreme and radical right subculture. On the other hand, its limited membership and formal centralization raise the question of whether it lives up to its mass party image. 


\section{The Alleged Mass Character of the VMRO-BND Organization}

\subsection{Formal Centralization and a Lightweight Organization}

The party has remained ambiguous on its formal organizational size and scope. In its early years, VMRO-BND claimed to have around 30,000 members (VMRO, 2001), although it has reported a declining membership of about 20,000 in more recent years (K. Krasteva et al., 2018). A much lower figure of 12,000 members is likely to be a more realistic assessment as indicated by independent reports (Spirova, 2005). Most of the party members are male, with higher education and relatively young, drawn predominantly from educational circles (usually historians), lawyers, as well as from the security forces like army and police (Ivanov \& Ilieva, 2005). These numbers, even if taken at face value, pale in comparison to VMRO-BND's political opponents. For example, the main center-right (GERB) and center-left (Balgarska Sotsialisticheska Partiya/Bulgarian Socialist Party) parties in Bulgaria claim to have around 100,000 members each (K. Krasteva et al., 2018), whereas the Dvizhenie za Prava i Svobodi (Movement for Rights and Freedoms), representing the sizeable Turkish minority in the country, claims to have about 40,000 active members in about 2,500 local organizations (K. Krasteva et al., 2018). Given its comparatively low membership numbers, VMRO-BND struggles to establish a strong organizational presence across Bulgaria. According to the party website (VMRO, 2020c), it currently does not have regional coordinators in six of the 28 provinces in the country, which suggests strong imbalances in its territorial outreach. This is further confirmed by data on its local organizations: The party currently claims to have 476 local party cells (i.e., structures with at least seven members as required by the party statutes) within the 282 municipalities of the country (K. Krasteva et al., 2018).

VMRO-BND has a lightweight organizational structure. The main body of the party is its congress, which convenes every three years. This body has the right to elect the main party institutions, including its party president, and to change the statutes. It cannot, however, pass the party program or manifesto (VMRO, 2020f). The party is led by the party president and the Natsionalen Izpalnitelen Komitet (NIK, National Executive Committee), the party executive organ that currently includes 16 members (VMRO, 2020e). Its members are also part of the larger Organizatsionen Savet (OS, Organizational Council), the main deliberative body between congresses that also includes local and regional leaders, and some of the official party-affiliated organizations, such as its youth and women's leagues (VMRO, 2020f). The latest data on the number of the members of the OS dates from 2012, with 66 members at the time (VMRO, 2012b). A final institution at the national level is the Natsionalna Kontrolna Komisiya (NKK, National
Control Commission), which handles disciplinary cases. Below these national structures, the party has a regional committee and a regional control commission for each of the 28 regions in Bulgaria and uses similar executive and deliberative structures at municipal and district levels (VMRO, 2020f).

The party statutes grant significant powers to the NIK, which is the institution that schedules the congress and the OS meetings and determines the agenda and outlines draft decisions. It has the right to decide on all matters that are not addressed in the statutes propose the territorial organization of the party and dictate rules on the legitimacy of any of its sub-national institutions (VMRO, 2020f). Beyond the NIK, only the OS could potentially exercise some substantial decision-making powers. The OS is the body responsible for confirming the party program, electoral manifestos, and electoral lists. It also gives the NIK the mandate to establish electoral alliances. Yet, given that all members of the NIK belong to the OS as well, the NIK has strong control over key party decisions even though the statutes nominally give these prerogatives to the party deliberative body (OS).

The informal affiliations of the party compensate for its centralized but lightweight formal structure and limited territorial outreach. VMRO-BND has a very active youth organization, as well as a women's association, both of which are the main providers of feet on the ground for party activities. The party also maintains a comprehensive network of loosely-affiliated organizations that promote the party or closely align with its views. This network creates the impression that VMROBND has strong roots in Bulgarian society, but nevertheless these organizations have limited social outreach and influence. Among these associations, the publishing house of VMRO-BND, Macedonia Press, which publishes historical and popular scientific literature, warrants particular attention. In the past, the party invested heavily in media publications, including a monthly conservative current affairs and history magazine, Nie (We), as well as a party newspaper, Bulgaria. VMRO-BND is further affiliated with the Makedonski Nauchen Institute (Macedonian Scientific Institute), which publishes historical and political analysis related to Macedonia with a nationalist slant. The party's increasing emphasis of socially conservative views and membership in the European Conservatives and Reformists group in the European Parliament more recently also allowed VMRO-BND to establish close relations with several independent organizations. Two of these organizations deserve particular attention. First, VMRO-BND has close ties to the Mladezhki Konservativen Klub (MKK, Young Conservatives Club), a student-led organization which regularly organizes events and publishes materials with conservative views. MKK serves as a pool of activists for VMRO-BND. For example, its former president, Krystian Szkwarek, was one of the most active party candidates during the 2019 European Parliament elections. Second, the party recently established close cooperation with 
ROD International (ROD standing for Roditeli Obedineni za Detsata/Parents United for the Children), a conservative think tank that supplies VMRO-BND with expertise on social questions.

\subsection{Promoting Nationalism Online and Offline}

Despite the limited membership numbers and centralized organizational structure, VMRO-BND remains very active during and between election periods, offering a broad variety of activities to its members and, by extension, the public at large. The party's significant degree of activism contrasts starkly with other parties in Bulgaria, which remain relatively inactive outside the electoral period and typically refrain from organizing activities for members and supporters. There are three main sets of activities that VMRO-BND uses to foster a sense of belonging and to "mainstream" nationalism in wider society. Firstly, the party hosts regular events that are usually attended by hundreds of people. These events are crucial and are mainly annual celebrations of figures and other events related to the Macedonian liberation movement, as well as key events in Bulgarian national history. Since its founding, the party has held mass torch rallies across the country on 27 November, commemorating the signing of the 1919 Treaty of Neuilly-sur-Seine which confirmed the Bulgarian defeat in World War I. In the past, VMRO-BND was also involved in the organization of the Lukov March, a neo-Nazi torch rally held each February in remembrance of Hristo Lukov, a Bulgarian army general and Nazi collaborationist. However, more recently the party has distanced itself from that event (Angelov, 2020).

Secondly, VMRO-BND regularly organizes local activities and events on the streets. VMRO-BND mobilizes protests addressing ongoing local issues or joins larger protests where it displays its flags. Usually, VMRO-BND is one of the main organizers of local action against ethnic or religious minorities, particularly the Turkish and Roma communities. These protests often result in violence (Stoykova, 2011), which was the case in 2011 following the murder of a local young person by an affiliate of one of the local Romani crime bosses in the village of Katunitsa. Further local actions include protests in front of places where religious minorities hold meetings, branding them as "sects," or attempts to block and intimidate the participants of the annual Sofia Pride march. VMRO-BND also regularly stages local protests against public service providers, such as the local electricity or water company, usually in opposition to high bills and charges.

Thirdly, apart from organizing commemorations and protests, VMRO-BND also regularly gathers signatures for local or national initiatives, such as a referendum on Turkish accession to the EU. These increase the party's visibility through street stalls and give party activists the feeling that they engage with the local community. All such activities are strengthened by leafleting to spread the party message.
These political actions are enhanced by activities that have a seemingly non-partisan character, yet in fact promote the party's views among the wider public and particularly to the Bulgarian youth. Party activists and members tend to join the work of local clubs to study and discuss Bulgarian history, usually from a nationalist perspective. Such clubs also stage reenactments of historical events, such as the Bulgarian Unification in Plovdiv every 6 September, which are well-attended by locals. The party's youth organization is quite active in university circles, where it holds regular talks and panels on topics related to Bulgarian history and politics. Within this, it organizes local essay or art competitions on nationalist topics. In the past it also did an annual amateur football tournament together with the local section of Blood \& Honor, an international neo-Nazi network that does not engage publicly in many activities throughout Bulgaria but remains known for its racist beliefs. Furthermore, VMRO-BND regularly organizes the cleanup and restoration of local areas, such as parks or playgrounds, under the banner of its campaign "Green is love of your country."

Beyond its sizable activities across the country, the party also maintains an online presence. Since its inception, VMRO-BND recognized the importance of media, as demonstrated above with its numerous publications. Online, the party maintains a website where it regularly reports its activities, while in 2014 it also created a partyaffiliated television channel, Bulgaria 24, which is freely accessible online. Additionally, most of VMRO-BND's members of parliament and its local party structures, as well as its youth and women's organizations, maintain Facebook pages with rich content, including statements, articles, pictures, and videos related to their activities. The party also has an up-to-date YouTube account with videos posted by its leading figures. Overall, VMRO-BND has an active online presence, which stands in noticeable contrast to its populist radical right partners from the OP alliance, Ataka and NFSB.

In terms of web presence, particular attention should be paid to major individuals in the party, specifically Angel Dzhambazki, party vice-president and current member of the European Parliament. Dzhambazki has long led the party youth organization and has developed a recognizable media profile as an articulate nationalist. This image is further enhanced by his social media presence. His controversial opinions, shared on his Facebook page, regularly attract a significant number of responses by party sympathizers and opponents. For example, following the murder of a student, he declared: "Tell me something about integration.... will tell you how to use a rope" (Zhelev, 2017). His behavior has been wellemulated by other major figures from VMRO-BND, such as Aleksandar Sidi and Carlos Contrera, who are also very active online, particularly on Facebook, despite not having a comparable impact to Dzhambazki. Generally, the online communication between the party and its supporters remains top-down, with the latter mainly 
commenting or sharing posts rather than being proactive (e.g., messaging for the party, posting comments in its support, quoting posts, or creating their own content). For example, Dzhambazki regularly holds a Facebook live session called Everything About Macedonia, where he comments on current affairs and responds to questions from the audience.

\subsection{Reasons for Growing an Active Community}

VMRO-BND and its leader have not spoken openly about any particular motivations to grow their base beyond providing generic statements about the importance of having party members. Nevertheless, the place of the party in Bulgarian society allows us to make an informed assumption on the potential reasons for growing its base. A look at the party's electoral performance suggests that an active membership has purposes other than electoral mobilization. VMRO-BND struggled until very recently to transform its membership into strong electoral support. Prior to its successful participation in the 2019 European Parliament elections and strong performance in the April 2021 parliamentary elections, the only other time the party participated in an election on its own was in 2013. In those elections it attracted only twice as many votes as the total number of its members. Under such circumstances, growing the membership seems to serve mainly social rather than electoral purposes.

Given the major commitment of the party to being active, growing its party base arguably serves three main aims. First, through its activities, VMRO-BND aims to create a sense of belonging among its (potential) members and activists, allowing them to jointly express their values and beliefs. This is enshrined in party documents, which emphasize that "loving one's country is [measured] even by the smallest acts; by any means one can be useful for its community" (VMRO, 2020b). The main reason for this emphasis of belonging lies in the party's origin as a cultural organization. The party statutes and party program list ambitious cultural and educational aims, such as to "preserve and develop traditional Bulgarian values, rites, and beliefs for the future generations" and to achieve "the spiritual unity of the Bulgarian people in Moesia, Thrace, Macedonia, the Western Outlands, and all other Bulgarian communities abroad" (VMRO, 2020f). This has been something that the party has worked toward even during its existence as VMRO-SMD, and it is these aims of cultural unity and preservation of cultural values that motivate the party to be active across communities.

Second, an active party organization demonstrates the party's roots within communities. For example, VMRO-BND regularly stages mass inaugurations for its new members, usually held at a church or a similarly symbolic building. Despite relying on rituals, including the kissing of a gun and a knife crossed over a bible as a form of inauguration, the party demonstrates a practical approach to growing its membership. The main aim of these mass inaugurations is to show the local significance and presence of VMRO-BND. Regularly those inaugurations are combined with local community work, through which the party spreads its message ("VMRO-BND razdava kurban i priema novi chlenove," 2011). Dated reports from the late 1990s suggest that such mass inaugurations were also used as a warning to political opponents, given that they were organized particularly at times of heightened tensions, such as when the Obedinena Makedonska Organizatsiya Ilinden-Pirin (United Macedonian Organization Ilinden-Pirin), a small Macedonian minority party, started its efforts to expand its party structures and register officially as a party in Bulgaria (Stoyanova, 1999).

Third, an active and mass organization shows public acceptance of party ideas. In this respect, the party's range of activities allow it to engage its current members, provide opportunities for its activists to demonstrate their abilities and grow within the party ranks, as well as to reach out to potential new members. Engagement with non-members is also important. The party's close links to several external organizations are an important source for the recruitment of new faces that are untarnished by party politics and can spread the party's views as independent figures. By doing so, VMRO-BND can claim that its ideas find wide acceptance beyond its party ranks. Such a strategy has been particularly prevalent in more recent years. For example, for the 2019 European Parliament elections, the party purposefully placed Andrey Slabakov, a non-member, second on its list. During the 2021 parliamentary elections in April and July, some of the most active figures of the party campaign were Kuzman Iliev, a former TV anchor, as well as Ernestina Shinova, a popular actress and Slabakov's wife.

\section{The Internal Centralization of VMRO-BND}

Despite the emphasis on presence and belonging when it comes to membership, VMRO-BND remains very centralized in its decision-making. The main reason for this centralization is Krasimir Karakachanov and his close affiliates' concentration of power and dominance in the party.

The leadership of VMRO-BND makes good use of its extensive formal rights. Throughout the years, Karakachanov and his clique in the party executive NIK single-handedly decided the electoral lists for national and European Parliament elections. They also forged electoral alliances and post-electoral coalitions, which were then rubber-stamped by the OS, although the OS formally holds the power to make such decisions. Nevertheless, the party leadership is very eager to present VMRO-BND as an organization open to wider society by providing space for non-members to engage with the party, particularly through participating in its electoral lists. In the 2013 parliamentary elections, VMRO-BND declared its aim to have more than half of its candidates selected from the so called "civic quota" 
i.e., placing non-members in its electoral lists (VMRO, 2013b). This allowed the party to demonstrate its close links to the wider radical right and extreme right subcultures. For example, in 2013 VMRO-BND placed two autonomous nationalists from Sandanski on its electoral lists. Given that electoral candidates had immunity from judicial prosecution at that time, this choice by the party served its efforts to release these two nationalists from police custody following their arrest for bombing the local party office of Evroroma (Euroroma), a small Romani minority party (VMRO, 2013a). At the local level, VMRO-BND demonstrates openness and reports document the party organizing local consultations with nonmembers, discussing who their local candidates should be and what issues they should address (VMRO, 2015).

Despite the significant room given to non-members, internal party democracy is severely limited. According to the party statutes, rank-and-file members have the right to propose decisions solely to the local party cells but not to any level above that (VMRO, 2020f). VMRO-BND remains dominated by the party leader and his close affiliates in the party executive. In office since 1997, Karakachanov survived several splits and challenges to his leadership through a heavy hand, using the strong formal powers of the party leadership. In each case where Karakachanov's leadership was under scrutiny, the outcome was often that the dissenters left the party or were expelled, while Karakachanov stayed on. In 1998, Karakachanov's choice to transform the then-cultural organization into a party led to a significant portion of members leaving in disagreement with this decision. The members who left founded a new cultural organization called VMRO-Sayuz na Makedonskite Organizatsii (VMRO-SMO, VMRO-Union of Macedonian Organizations). In 2000 another alternative VMRO organization was founded, claiming to be the true heir of the historic VMRO. Karakachanov managed to dismiss these challenges, accusing both alternative VMRO organizations of trying to steal the party's properties ("VMRO-Malkiyat David sreshtu golemite partii," 2000). In 2001, the Sofia youth organization of the party criticized Karakachanov during the party congress, saying that VMRO-BND had lost its direction and directly accused Karakachanov of using the party for personal gain. The outcome of this criticism was the immediate removal of the VMRO member who read the declaration and the dissolution of the Sofia youth organization ("Ima li pochva u nas kauzata VMRO," 2001).

The main evidence of the limited internal democracy and heavy concentration of power within the party also comes from the outcome of the internal challenges to Karakachanov's leadership. There have been two major examples in recent times: In 2009 the then-Plovdiv mayor, Slavcho Atanasov, lost marginally on the final delegate vote ("Slavcho Atanasov: Bitka do dupka za VMRO," 2009), while in 2012 Kostadin Kostadinov, the leader of the Varna branch and party vice-president, lost by a landslide (Kostadinova, 2020). On both occasions, the results were openly disputed by the challengers, who accused Karakachanov of vote manipulation. Furthermore, both cases were challenges to Karakachanov's leadership from his own inner circle, suggesting the absence of any alternative sources of power in VMRO-BND. A potential successor to the party presidency is currently Angel Dzhambazki, but there is no indication that he developed an internal opposition to Karakachanov. Instead, it seems that he will inherit the position if he does not do anything to contradict Karakachanov. Overall, with no alternative sources of power, limited dissent, heavy crackdown when such dissent occurs, and strong formal and actual centralization around the party leadership, VMRO-BND has limited internal party democracy despite its effort to present itself as a party open to wider society.

\section{Conclusion}

VMRO-BND is a clear case of a PRRP that invests considerable effort in building a mass party organization. Despite having a rather limited membership, the party has an active organization across local communities, strong online presence, and a good network of loosely-affiliated organizations. Its activities across communities attract members and activists as they create a sense of belonging to the organization, showcase the party's roots within society and present party ideas as having broad social acceptance. The role of the internet and the social media is important for the party as VMRO-BND maintains multiple channels to interact with activists, members, and supporters (including a TV channel owned by the party, multiple Facebook accounts, and an up-to-date YouTube channel). Organizationally, the party remains centralized with limited internal democracy, despite its attempts to offer some room to non-members and local activists.

The experiences of VMRO-BND lead to three major lessons about the contemporary state of the organization of a PRRP, particularly from Central and Eastern Europe. First, PRRPs from the region seem to acknowledge the importance of local presence and activities, and, generally, of organizational strength. In the case of VMRO-BND, it allowed the party to keep its activists and members engaged and to tap into popular nationalist sentiments. In addition to the creation of a sense of belonging, the cultural and educational emphasis of these activities is particularly attractive to younger members. This echoes the experiences of Jobbik in Hungary, for example, where the party grew a significant youth base (Pirro \& Róna, 2019). Second, PRRPs in Central and Eastern Europe can create the impression of being mass organizations, even if formally they may have limited membership numbers. This relates to the thick network of loosely-affiliated organizations and joint actions with other representatives of the radical and extreme-right milieus that VMRO-BND managed to forge throughout the years. The VMRO-BND affiliates can often provide feet on the ground for the party activities or supply it with nominally independent candidates on its electoral 
lists - a finding that has been highlighted in previous work on radical right parties and their subcultures in Central and Eastern Europe (Minkenberg, 2017). Third, we need to acknowledge the importance of local party activists who provide the key link between the party, the radical and extreme-right subcultures, and the wider society. In the case of VMRO-BND, it is the activities of local activists and members that really allowed the party to engage with communities and establish a certain profile. This confirms the importance of party organization rather than leadership control for the sustainable organizational and electoral development of challenger parties in Central and Eastern Europe, as indicated in existing studies (Gherghina \& Soare, 2021).

Based on these discussions, future works may wish to explore three important topics. First, more attention to the party's grassroots efforts is needed. Given the importance of local activists and their work in local communities, we may need to shift our focus from PRRPs at the national level and explore local strategies, i.e., the role and place of local activists, their freedom to act as they see fit in promoting the party message, etc. Second, we also need to turn our focus to the main reservoir for PRRPs: the radical right subculture. Rather than studying openly right-wing organizations, we may need to pay a closer attention to the work of nominally non-partisan organizations that essentially "mainstream" the views of PRRPs, offline and online. Finally, while we looked mainly at the offline activities of PRRPs, further research could focus on its online activities. We noticed that VMRO-BND has increasingly utilized social media and other online channels, so a greater understanding of the party's online behavior would add to the growing academic interest in the relationship between internet and PRRPs in Europe (Karl, 2017; Schumann et al., 2021). It is important to explore how parties use these channels particularly to mobilize their members and communicate with sympathizers and voters.

\section{Acknowledgments}

The authors would like to thank the editors of this thematic issue, Daniele Albertazzi and Stijn van Kessel, for their support in preparing the article, as well as the participants of the workshop "Central and Eastern Europe in Post-Communism: Understanding the Political, Social and Historical Developments" for their helpful feedback on an earlier version of the article.

\section{Conflict of Interests}

The authors declare no conflict of interests.

\section{References}

Angelov, G. (2020, September 9). VMRO se otreche ot Lukov marsh, sled kato DPS gi posochiha za organizatori [VMRO renounced Lukov March after DPS declared them as organizers]. Dnevnik. https://www. dnevnik.bg/bulgaria/2018/02/09/3126888_vmro_ se_otreche_ot_lukov_marsh_sled_kato_dps_gi

Avramov, K. (2015). The Bulgarian radical right: Marching up from the margins. In M. Minkenberg (Ed.), Transforming the transformation? The East European radical right in the political process (pp. 299-318). Routledge.

Central Electoral Commission. (2017). Parlamentarni Izbori 2017 [Parliamentary elections 2017]. https:// results.cik.bg/pi2017/rezultati

Central Electoral Commission. (2019). Izbori za Evropeyski parlament 2019 [European Parliament elections 2019]. https://results.cik.bg/ep2019/ rezultati

Contrera, C. (2019, April 3). Krizata na elitite [The crisis of the elites]. VMRO. https://vmro.bg/кризата-наелитите

Gherghina, S., Miscoiu, S., \& Soare, S. (2017). How far does nationalism go? An overview of populist parties in Central and Eastern Europe. In R. C. Heinisch, C. Holtz-Bacha, \& O. Mazzoleni (Eds.), Political populism: A handbook (pp. 193-208). Nomos.

Gherghina, S., \& Soare, S. (2021). Electoral performance beyond leaders? The organization of populist parties in postcommunist Europe. Party Politics, 27(1), 58-68.

Ibroscheva, E. (2020). The world according to Siderov: The rise of the far-right celebrity politician in Bulgaria. Celebrity Studies, 11(3), 305-319.

Ima li pochva u nas kauzata VMRO [Is there any ground for the VMRO cause]. (2001, December 22). Banker Weekly. https://www.banker.bg/obshtestvoi-politika/read/ima-li-pochva-u-nas-kauzata-vmro

Ivanov, C., \& Ilieva, M. (2005). Bulgaria. In C. Mudde (Ed.), Racist extremism in Central and Eastern Europe (pp. 1-28). Routledge.

Karl, P. (2017). Hungary's radical right 2.0. Nationalities Papers, 45(3), 345-355.

Kopecký, P., \& Mudde, C. (Eds.). (2003). Uncivil society? Contentious politics in post-Communist Europe. Routledge.

Kostadinova, S. (2020, February 5). Kostadin Kostadinov "Kopeykin"-Noviyat Siderov [Kostadin "Kopeykin" Kostadinov-The new Siderov]. Mediapool. https:// www.mediapool.bg/kostadin-kostadinov-kopeikinnoviyat-siderov-news303086.html

Krasteva, A. (2016). The post-Communist rise of national populism: Bulgarian paradoxes. In G. Lazaridis, G. Campani, \& A. Benveniste (Eds.), The rise of the far right in Europe: Populist shifts and "othering" (pp. 161-200). Springer.

Krasteva, K., Klisurova, L., \& Dimitrova, R. (2018, August 6). BSP i GERB veche pochti ravni po broy chlenove [BSP and GERB almost equal in membership numbers]. 24 Chasa. https://www.24chasa.bg/ novini/article/6996938

Mesežnikov, G., Gyárfášová, O., \& Smilov, D. (2008). Pop- 
ulist politics and liberal democracy in Central and Eastern Europe. Institute for Public Affairs.

Minkenberg, M. (2015). Transforming the transformation? The East European radical right in the political process. Routledge.

Minkenberg, M. (2017). The radical right in Eastern Europe. Democracy under siege? Palgrave Macmillan.

Pirro, A. (2015). The populist radical right in Central and Eastern Europe. Routledge.

Pirro, A., \& Róna, D. (2019). Far-right activism in Hungary: Youth participation in Jobbik and its network. European Societies, 21(4), 603-626.

Pytlas, B. (2016). Radical right parties in Central and Eastern Europe: Mainstream party competition and electoral fortune. Routledge.

Schumann, S., Boer, D., Hanke, K., \& Liu, J. (2021). Social media use and support for populist radical right parties: Assessing exposure and selection effects in a two-wave panel study. Information, Communication \& Society, 24(7), 921-940.

Slavcho Atanasov: Bitka do dupka za VMRO [Slavcho Atanasov: Fight until the end for VMRO]. (2009, October 19). Maritsa. https://www.marica.bg/balgariq/ slavcho-atanasov-bitka-do-dupka-za-vmro

Spirova, M. (2005). Political parties in Bulgaria: Organizational trends in comparative perspective. Party Politics, 11(5), 601-622.

Stoyanova, G. (1999, February 20). Dalgiyat pat na VMRO kam vlastta [The long path of VMRO to power]. Kapital. https://www.capital.bg/politika_i_ ikonomika/bulgaria/1999/02/20/248969_dulgiiat_ pohod_na_vmro_kum_vlastta

Stoykova, A. (2011, April 18). VMRO i svideteli na Yehova se bili v Burgas [VMRO and Jehova's Witness fought in Burgas]. BNT. https://bntnews.bg/bg/a/51251vmro_i_svideteli_na_jehova_se_bili_v_burgas

Sygkelos, Y. (2015). Nationalism versus European integration: The case of ATAKA. East European Quarterly, 43(2/3), 163-188.

Todorov, A. (2013). The extreme right wing in Bulgaria. Friedrich Ebert Stiftung.

VMRO. (2001). Napredak za Bulgaria [Progress for Bulgaria]. VMRO. http://www.vmro.bg/napredak.htm

VMRO. (2008). Zadachi i programa [Tasks and program]. VMRO. http://vmro.bg/modules.php?name= Programa

VMRO. (2012a). 22 godini ot vazstanovyavaneto na VMRO sled demokratichnite promeni $v$ Bulgaria [22 years since the restoration of VMRO after the democratic changes in Bulgaria]. VMRO. https:// vmro.bg/22-godini-ot-vzstanoviavaneto-na-vmrosled-demokra

VMRO. (2012b). Rakovodni organi [Governing bodies].
VMRO. http://www.vmro.bg/index.php?option= com_content\&view=article\&id=64\&Itemid $=30$

VMRO. (2013a). Momchetata ot Sandanski vlizat $v$ listite na VMRO [The boys from Sandanski enter the VMRO lists]. VMRO. https://vmro.bg/momchetataot-sandanski-vlizat-v-listite-na-vmro

VMRO. (2013b). VMRO s yasno litse na izborite i shiroka grazhdanska lista [VMRO with a clear face on the elections and wide civic list]. VMRO. https:// vmro.bg/vmro-s-iasno-litse-na-izborite-i-shirokagrazhdans

VMRO. (2015). Troyan nominira kandidati za izborite sled obshtestveno dopitvane [Troyan nominates candidates for the elections following public consultation]. VMRO. https://vmro.bg/вмро-троян-номиниракандидати-за-изборите-след-общественодопитване

VMRO. (2020a). Demografska programa "Bulgaria 2050" [Demographic program "Bulgaria 2050"]. VMRO. https://vmro.bg/българия-2050

VMRO. (2020b). Koi sme nie [Who are we]. VMRO. https://vmro.bg/кои-сме-ние

VMRO. (2020c). Kontakti [Contacts]. VMRO. https:// vmro.bg/контакти

VMRO. (2020d). Programa [Program]. VMRO. https:// vmro.bg/програма

VMRO. (2020e). Rakovodni organi [Governing bodies]. VMRO. https://vmro.bg/ръководни-органи

VMRO. (2020f). Ustav [Statutes]. VMRO. https://vmro. bg/устав

VMRO. (2021). Dohodi, semeystvo, sigurnost [Income, family, security]. VMRO. https://vmro.bg/ предизборна-програма-на-вмро-2021-г

VMRO-BND razdava kurban i priema novi chlenove [VMRO-BND provides gifts and accepts new members]. (2011, July 19). Darik Radio. https://dariknews. bg/regioni/plovdiv/vmro-bnd-razdava-kurban-ipriema-novi-chlenove-750200

VMRO-Malkiyat David sreshtu golemite partii [VMROThe small David against the giant parties]. (2000, June 20). Standart. http://paper.standartnews.com/ archive/2000/06/20/society/analis3.htm

Werkmann, C., \& Gherghina, S. (2018). Organized for parliament? Explaining the electoral success of radical right parties in post-Communist Europe. Government and Opposition, 53(3), 461-485.

Zankina, E. (2017). Populism, voters and cleavages in Bulgarian politics. Politologický Časopis, 24(1), 56-71.

Zhelev, Z. (2017). Dzhambazki kam roma, ubil Aleks: Shte vi razkazha kak se polzva vazhe [Dzhambazki to the Romani who killed Aleks: I will tell you how to you use a rope]. Dnes.bg. https://www.dnes.bg/ obshtestvo/2017/07/17/djambazki-kym-roma-ubilaleks-shte-vi-razkaja-kak-se-izpolzva-vyje.347509 


\section{About the Authors}

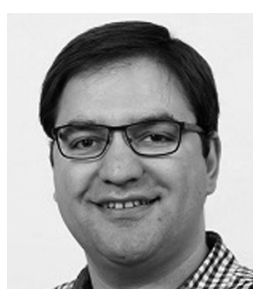

Petar Bankov is a postdoctoral researcher at the University of Glasgow. His research interests are in comparative party politics, particularly in the local dynamics between party organizations and local communities. His previous work studied the electoral geography of the European radical left since 1990.

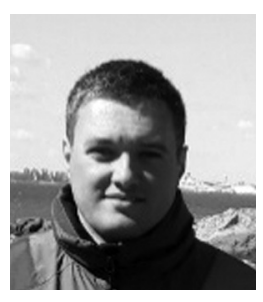

Sergiu Gherghina is an associate professor in comparative politics at the Department of Politics and International Relations, University of Glasgow. His research interests lie in party politics, elite and voting behavior, democratization, and the use of direct democracy.

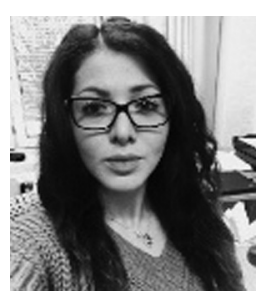

Nanuli Silagadze is a postdoctoral researcher at Åbo Akademi University, Finland. Her main areas of research include democratic innovations with a particular focus on the instrument of direct democracy, political parties, and voting behavior. 